\title{
A dação de bens hipotecados pelo devedor concordatario para a solução da divida
}

\author{
P A R E C E R
}

Não priva a propositura da concordata preventiva ao devedor da administração e da posse dos seus bens. Durante o seu processo, esclarece 0 art. 156 do decr. n. 5.746 , de 9 de dezembro de 1929, ele conservará a administração de seus bens e continuará com o seu negocio, sob a fiscalização do comissario, mas não poderá alienar ou hipotecar imoveis, nem constituir penhores, nem contrair novas obrigações, salvo com expressa autorização do juiz, por evidente utilidade, ouvido o comissario.

Não lhe será licito, portanto, em face dêsse dispositivo legal, tão precioso e claro, dar bens hipotecados em pagamento da divida, que garantam. A dação em pagamento é uma fórma de alienação de bens. Se a impedisse, em todos os casos, sem exceção alguma, criaria a lei, entretanto, situação desfavoravel ao devedor. Teria ele de sofrer o executivo hipotecario, afim de, em praça, ser o imovel vendido e embolsar-se o credor hipotecario do produto da arrematação; ou arremata-lo ele proprio, em beneficio de seu crédito, se não preferir adjudica-lo em pagamento da divida. Com o executivo, todavia, teria o devedor o seu passi- 
vo acrescido com as despesas e custas do processo, os juros do tempo decorrido e a multa estipulada para o caso de cobrança judicial. A dação em pagamento, por conseguinte, seria e será de evidente utilidade, se não houver desproporção entre o valor dos bens hipotecados e a importancia total do crédito hipotecario.

Permite a lei, no emtanto, a alienação dos imoveis do concordatario, com autorização expressa do juiz, por evidente utilidade, ouvido o comissario.

Nada se opõe, no caso vertente, requeira o concordatario ao juiz de direito, que dirije e superintende o processo de sua concordata preventiva, a autorização para dar em pagamento da divida os bens hipotecados, fazendo a demonstração da sua evidente utilidade. Esta poderá ficar patente por avaliação deles por perito nomeado pelo juiz. Ouvido o comissario, seja o seu parecer pró ou contra a operação, se $n$ juiz conceder a autorização, não vejo como possam os credores, que seriam os unicos interessados nas provaveis sobras da execução hipotecaria, impugnar o negocio ou, realizado ele, pleitcar-lhe a anulação por of ensivo do seu direito creditorio.

Estando a proposta de concordata em processo regular, isso naturalmente aconteceu pelo haver o cancordatario oferecid $n$, confórme o preceituado no art. $149, \S 1 .^{\circ}$, as garantias reais ou pessoais assecuratorias do pagamento de mais de cincoenta por cento. Se foi a fideijussoria a garantia apresentada, sem dúvida, pelo disposto no n. 6 , do $\S 20^{\circ}$ do mesmo art. 149, exibidos foram "documentos comprobatorios da idoneidade financeira do fiador oferecido" Se a dada foi a garantia real, não somente se comprovou a propriedade dos bens oferecidos e de se acharem livres de onus de qualquer especie, como, ainda, terá o comissario, com assistencia do representante do Ministerio Publico, recebido, em nome dos credores, a respectiva escritura de garantia, como determina o n. 8 do $\S 1 .^{\circ}$ do art. 151.

Se homologada fôr, por sentença, a concordata preventiva, terão os credores quirografarios, os sujeitos aos iseus 
efeitos, inteiramente resguardado o seu direito creditorio, ou com garantia real, ou com garantia pessoal. Careceriam de interêsse, portanto, ou para impugnar a dação em pagamento, ou para anulá-la, a menos que os bens a serem dados lhes tivessem sido of erecidos, tambem, em segunda hipoteoa, o que, no caso, não se verificou.

Outros credores privilegiados, acaso existentes, tambem não poderiam opôr-se á dação, pelo se acharem, por seu turno, devidamente garantidos.

Desde que, em suma, fique, no processo e nos autos da concordata preventiva, demonstrada a evidente utilidade da dação em pagamento, de que se cuida, e o juiz a autorize, depois de ouvido o comissario, agirá com prudencia e com acerto, aceitando a dação em pagamento.

São Paulo, 12 de março de 1932. 